\title{
Performance of broiler fed on diet containing Koroch (Pongamia pinnata) seed cake
}

\author{
Husna AU ${ }^{1}$, M Habib ${ }^{2}$, MT Islam ${ }^{3}$, AJM Ferdaus ${ }^{1}$ and MS Ali ${ }^{1}$ \\ ${ }^{1}$ Department of Poultry Science, Bangladesh Agricultural University (BAU), Mymensingh-2202; ${ }^{2}$ Graduate \\ Training Institute, BAU; ${ }^{3}$ Nourish Poultry and Hatchery Ltd. Uttara, Dhaka-1230
}

\begin{abstract}
A total of 180 day old broiler chicks (Cobb 500) were allocated randomly to five treatment groups with 3 replicate having 12 birds in each reared for a period of 28 days. The aim of this study was to find out whether koroch seed cake (KSC) had any effect upon broiler at different age group. Therefore, two diets were formulated: 1 ) basal diet with $0 \% \mathrm{KSC}$ and 2) basal diet with $2 \% \mathrm{KSC}$. The birds of different treatment groups received either diet $\mathrm{i}$ or $\mathrm{ii}$ in the following way: Control group $\left(\mathrm{T}_{1}\right)=0 \% \mathrm{KSC}$ throughout the experimental period, $\mathrm{T}_{2}=1$ st 21 days $0 \% \mathrm{KSC}$ diet + rest 7 days $2 \% \mathrm{KSC}$ diet, $\mathrm{T}_{3}=1 \mathrm{st}$ 14 days $0 \% \mathrm{KSC}$ diet + rest 14 days $2 \% \mathrm{KSC}$ diet, $\mathrm{T}_{4}=1$ st 7 days $0 \% \mathrm{KSC}$ diet + rest 21 days $2 \% \mathrm{KSC}$ diet, and $T_{5}=2 \% \mathrm{KSC}$ throughout the experimental period. Body weight, body weight gain, feed consumption and mortality of broilers were recorded weekly and also whole experimental period. Feed conversion ratio (FCR) was also calculated. Weekly body weight and body weight gain did not show significant differences during 1st, 2nd and 4th week of age, while significant differences were found in 3rd week of age. In 3rd week, the body weight and body weight gain was the lowest in $\mathrm{T}_{5}$ (fed $2 \% \mathrm{KSC}$ diet) among the Treatments. The final body weight was 906.69, 864.05, 869.92, 860.87 and $838.89 \mathrm{~g}$ for $T_{1}, T_{2}, T_{3}, T_{4}$ and $T_{5}$, respectively and found non-significant result. Similar pattern of result found in body weight gain of the birds. Feed intake and feed conversion ratio of birds at different weeks and during whole experimental period did not differ significantly $(p>0.05)$. All the meat yield parameters showed a non-significant effect of age of broilers fed with $2 \% \mathrm{KSC}$. Results of this experiment revealed that the feeding of $2 \% \mathrm{KSC}$ at different ages fail to show any significant effect on broiler performance.
\end{abstract}

Key words: live weight gain, koroch seed, age, broiler

\section{Introduction}

A major constraint to poultry production in Bangladesh is the scarcity and fluctuating quantity and quality of the year round feed supply. Providing adequate good quality feed to broiler to raise and maintain their productivity will be a major challenge all over the world. Furthermore, the competitive demand for conventional feed resources as food between poultry and man. Future hopes of feeding the millions and safe guarding their food security will depend on the enhanced and efficient utilization of unconventional resources that cannot be used as food for humans, as feed for livestock and poultry. A possible and perhaps the most viable proposition could be the inclusion of unconventional feed resources in poultry rations with suitable and complete feed technology that can utilize the feed sources with maximum efficiency.
Producers are always trying with different approaches for better growth and economic production of broiler (Amata, 2014). The feed cost incurred about $60-65 \%$ of the total cost of poultry production (Banerjee, 1998) and protein cost incurred $13 \%$ of total feed cost for poultry production (Singh, 1990). Availability of quality feed at a reasonable cost is a key to successful poultry operation. Good quality feed specially protein rich feed is the most important constraint to improving the productivity of poultry in Bangladesh. The animal nutritionists are thus compelled to explore the possibilities of feeding non-edible and non-competitive unconventional agro-forest based industrial byproducts to meet the nutritional requirement of the animals. Since protein sources are costly by products are gaining momentum as alternate feed resources for the poultry industry due to chronic shortage of protein and energy rich animal feeds in Bangladesh and other South East Asian countries. Pongamia pinnata known as Koroch in Bangladesh and Karanj in India can be used as

*Corresponding author: mdshawkatali@hotmail.com 


\section{Koroch seed for broiler production}

unconventional feed stuffs. It is very available in the highways, roads, haors and canals of Sylhet areas, Sundorbans mangrove forest in Khulna region of Bangladesh and it is native to the Asian subcontinent. Koroch is one of the nitrogen fixing trees. Air dried kernel have $19.0 \%$ moisture, $27.5 \%$ fatty oil, $17.4 \%$ protein, $6.6 \%$ starch, $7.3 \%$ crude fibre and $2.4 \%$ ash (James, 1983). In India, where there is the most experience with this tree, the seeds are collected to obtain Karanja or Honge oil. The non-edible oil is known for its medicinal properties. There is a long history of using the oil as a fuel for lamps and cooking stoves. The pressed cake is used as an insect repellant and as an organic fertilizer because it contains fixed Nitrogen (4\%), Phosphorus (1\%) and Potassium (1\%) (Pavanaram and Ramchandra, 1995).

Throughout the world koroch is used as herbal products, but in Bangladesh no care is taken to use it. Huge amount of Koroch seeds in Bangladesh was not tested to introduce as poultry feed, despite a suitable chemical composition. The oil cake, when extracted from the seeds, is used as a feed to be cheaper than soybean meal (James, 1983). Natanam et al. (1989) stated that the concentration of tannins was $23.2 \mathrm{~g} / \mathrm{kg}$ DM and trypsin inhibitor was 62 $\mathrm{g} / \mathrm{kg}$ protein in Koroch seed. The oil has a high content of triglycerides, and its disagreeable taste and odor for bitter flavonoid constituents, pongamin and karanjin (Allen and Allen, 1981). Feeding of de-oiled koroch cake after extraction at high level (>5\%) adversely affect the performance (Natanam et al., 1989; Dhara et al., 1997) due to residual toxin left in the solvent extracted cake.

Thus, this study investigated the effect of oil extracted Koroch seed cake on growth, meat yield and survivability of broilers fed on difference ages at lower level (only $2 \%$ ).

\section{Materials and Methods}

The experiment was conducted at Bangladesh Agricultural University poultry farm, Mymensingh for a period of 28 days by using Cobb-500 day old broiler chicks to find out the effect of oil extracted Koroch seed cake (KSC) feeding at different ages on performance of broilers. A total of 180 day-old broiler chicks (DOC) were purchased from "Nourish Poultry and Hatchery Ltd" Shreepur, Gazipur, Bangladesh. Koroch seed were collected from Derai Upazila of Sunamganj district and Botanical garden of BAU. The oil from
Koroch seeds was expelled locally from an oil extraction mill. Then the remaining cake was dried and proximate analysis was performed as per AOAC (1995). The moisture (\%), CP (\%), Ash (\%), CF (\%) and EE (\%) of KSC was 12.3, 23.19, 5.0, 2.37 and 10.0, respectively.

The chicks were randomly distributed to five treatments $\left(T_{1}, T_{2}, T_{3}, T_{4} \& T_{5}\right)$ having three replication of each treatment. The chicks are reared in separated pens according to treatment and replications. Each treatment group consists of 36 chicks and the number of chicks each replication was 12 . Two diets were formulated; one is without $\mathrm{KSC}$ and another is with $2 \% \mathrm{KSC}$. The birds were fed either one of the 2 diets at different ages of 28 days experimental period. Those were: Control group or $\mathrm{T}_{1}=0 \% \mathrm{KSC}$ throughout the experimental period, $\mathrm{T}_{2}=1 \mathrm{st}$ 21days $0 \%$ KSC diet + last 7 days $2 \%$ KSC diet, $\mathrm{T}_{3}=1$ st 14 days $0 \% \mathrm{KSC}$ diet + last 14 days $2 \%$ $\mathrm{KSC}$ diet, $\mathrm{T}_{4}=1$ st 7 days $0 \% \mathrm{KSC}$ diet + last 21 days $2 \% \mathrm{KSC}$ diet, and $\mathrm{T}_{5}=2 \% \mathrm{KSC}$ throughout the experimental period.

The birds were given $0.91 \mathrm{~m}^{2}$ floor space within the experimental pen. The experimental house and pens were cleaned, washed and disinfected properly. At the same time, all necessary equipments were cleaned and disinfected before the arrival of chicks. Fresh dried rice husk was spread on the floor of the pens at a depth of 4 $\mathrm{cm}$. After 3 weeks of age, upper layer of the litter with droppings were removed and replaced by new litter material. Every weeks litter was stirred to prevent accumulation of ammonia gas and maggot formation. A 100 watt electric bulb for each pen was used for chick brooding.

After arrival of chicks in the experimental house, they were supplied $5 \%$ glucose solution to minimize transportation stress. For the first 7 days, feeds were given on paper and water was supplied in a round waterer. One feeder and one waterer were provided for each pen. Feeds and water were supplied ad libitum to all broilers. The broilers were vaccinated against Newcastle Disease and Infectious Bursal Disease (Gumboro). The chicks were individually weighed at the beginning of the experiment (initial body weight) and allocated to different replication pens of each of the 5 treatment groups. Body weight was also measured on a weekly basis for all birds from each replication. The average body weight gain, feed consumption and feed conversion ratio were calculated weekly and whole experimental 
Husna et al. (2017) Bang. J. Anim. Sci. 46 (2):88-94

period. Survivability was measured from the whole experimental period.

At the end of feeding trial, one broiler weighing average from each pen was randomly selected for recording meat yield parameters. Broilers were fasted from feed and water for twelve hours prior to slaughtering. After complete bleeding, birds were immersed in hot water $\left(51-55^{\circ} \mathrm{C}\right)$ for 120 seconds for proper defeathering manually. After defeathering, the birds were again individually weighed. Then head, shank, viscera, giblet (heart, liver and gizzard) and abdominal fat were removed for determination of meat yield parameters. Dressed broilers were cut into different parts such as breast, thigh, drumstick and wing. Finally, every cut up parts were weighed and recorded separately for each broiler of all replications.

All recorded and calculated data were statistically analyzed using analysis of variance technique by a computer using SAS statistical package program in accordance with the principles of Completely Randomized Design (SAS, 2009). DMRT was done to compare variations among treatments where ANOVA showed significant differences.

\section{Results and Discussion}

\section{Live weight}

The live weight of broilers of different treatment groups at different ages is shown in Table 2 . During the first week the live weight of birds did not show significantly different $(p>0.05)$ among the treatment groups. The $T_{5}$ group fed $\mathrm{KSC}$ from the first day attained $143 \mathrm{~g}$ body weight, where the other groups $T_{1}, T_{2}, T_{3}$ and $T_{4}$ attained 145, 143,141 and $144 \mathrm{~g}$ respectively. At 21 days of age, the body weight found significantly different among different treatment groups $(p<0.01)$. No significant differences were found in final body weight among different treatments at 28 days experimental period. Control group attained $906 \mathrm{~g}$ body weight, where other group attained $864 \mathrm{~g}$, $869 \mathrm{~g}, 860 \mathrm{~g}$ and $838 \mathrm{~g}$ respectively. Although no significant differences were found, the treatment $\mathrm{T}_{5}$ fed koroch cake at $2 \%$ level throughout the experimental period had the lowest body weight, while the highest was in the control $(p=0.07)$. Dhara et al. (1997) reported that deoiled karanj cake could be included in the diet to a maximum level of $4.45 \%$. Mandal and Banerjee (1979) recommended that deoiled karanj cake $(\mathrm{EE}<0.05 \%)$ could safely be included at $5 \%$ in the diet of broiler chicken.

Table 1. Ingredients and nutrient composition (\%) of starter and grower diet

\begin{tabular}{lcccc}
\hline \multirow{1}{*}{ Ingredients } & Starter diet (day-old-20 days) & \multicolumn{2}{c}{ Grower diet (21-28 days) } \\
\cline { 2 - 5 } & 0\% KSC & 2\% KSC & 0\% KSC & 2\% KSC \\
\hline Maize & 61.0 & 59.9 & 65.05 & 63.44 \\
Rice polish & 2.0 & 2.0 & 2.00 & 2.00 \\
Soybean meal & 24.9 & 24.0 & 20.69 & 19.91 \\
Protein concentrate & 9.0 & 9.0 & 7.50 & 7.50 \\
DCP & 2.0 & 2.0 & 0.25 & 0.25 \\
Vit-min & 0.25 & 0.25 & 0.20 & 0.20 \\
Methionine & 0.20 & 0.20 & 0.15 & 0.15 \\
lysine & 0.15 & 0.15 & 0.50 & 0.50 \\
Common salt & 0.50 & 0.50 & 2.00 & 2.00 \\
Vegetable oil & 0.00 & 0.00 & 1.66 & 2.05 \\
Koroch cake & 0.0 & 2.0 & 0.00 & 2.00 \\
Nutrient composition & & & & \\
ME(Kcal/Kg) & 2971 & 2952 & 3100 & 3100 \\
Crude Protein(CP\%) & 22.38 & 22.37 & 20.00 & 20.00 \\
Crude fibre (CF\%) & 3.82 & 3.78 & 3.01 & 3.56 \\
Calcium & 1.28 & 1.28 & 1.20 & 1.19 \\
Av.Phosphorus & 0.71 & 0.71 & 0.68 & 0.67 \\
Lysine & 1.30 & 1.27 & 1.14 & 1.12 \\
Methionine & 0.55 & 0.54 & 0.52 & 0.51 \\
\hline
\end{tabular}




\section{Koroch seed for broiler production}

\section{Live weight gain}

Live weight gain of the birds of different treatment groups is also given in Table 2. Weekly live weight gain of birds were not significantly differ $(p>0.05)$ among the groups during 1 st $2^{\text {nd }}$ and $4^{\text {th }}$ weeks of age. However, significant differences were found at $3^{\text {rd }}$ weeks of age. The result of live weight gain showed similar trend like live weight. Although no significant differences were found in whole experimental period, the higher body weight gain in the whole experimental period was found in control $(860 \mathrm{~g})$ fed $0 \% \mathrm{KSC}$, while the lower body weight gain was found in $T_{5}$ group which fed KSC from first day $(p=0.0766)$. The result of this experiment agreed with the result of Dhara et al. (1997), who reported that deoiled karanj cake could be included in the diet to a maximum level of $4.45 \%$. Our result also agreed with Mandal and Banerjee (1979), who recommended that deoiled karanj cake $(\mathrm{EE}<0.05 \%$ ) could safely be included at $5 \%$ in the diet of broiler chicken.

\section{Feed consumption}

Feed consumption of bird under different treatment groups during day 7, 14, 21 and 28 of age did not differ significantly $(p>0.05)$. The Cumulative feed intake of whole experimental period was $1394.05,1407.67,1394.67,1381.50$ and $1420.19 \mathrm{~g}$ for the treatments $T_{1}, T_{2}, T_{3}, T_{4}$ and $T_{5}$, respectively. Panda et al. (2008) noticed adverse effect on growth and feed intake was noticed when daily karanjin intake was $18 \mathrm{mg}$ and above. Probably the higher daily karanjin intake $(>18 \mathrm{mg}$ ) could be the probable reason for showing adverse effect. Similarly Natanam et al. (1989) reported the adverse effect of karanj cake feeding is due to the leftover karanjinin the processed cake. In the present study using $2 \%$ of $\mathrm{KSC}$ did not appear any noticeable change in feed intake due to the less leftover of karanjinin.

Table 2. The weekly performance of broilers fed on oil extracted KSC at different ages

\begin{tabular}{|c|c|c|c|c|c|c|c|}
\hline \multirow[t]{2}{*}{ Parameters } & \multirow{2}{*}{$\begin{array}{l}\text { Age } \\
\text { (wk) }\end{array}$} & \multicolumn{5}{|c|}{ Different treatment groups } & \multirow{2}{*}{$\begin{array}{l}\text { Level of } \\
\text { Significa } \\
\text { nce }\end{array}$} \\
\hline & & $\begin{array}{l}0 \% \text { KSC diet } \\
\text { from } 1 \text { st day }\end{array}$ & $\begin{array}{l}2 \% \text { KSC diet } \\
\text { from } 21 \text { day }\end{array}$ & $\begin{array}{l}2 \% \text { KSC diet } \\
\text { from } 14 \text { day }\end{array}$ & $\begin{array}{l}2 \% \text { KSC diet } \\
\text { from } 7 \text { day }\end{array}$ & $\begin{array}{l}2 \% \text { KSC diet } \\
\text { from } 1 \text { st day }\end{array}$ & \\
\hline \multirow{5}{*}{$\begin{array}{l}\text { Body weight } \\
\text { (g) }\end{array}$} & DOC & $46.2 \pm 0.35$ & $46.1 \pm 0.68$ & $45.8 \pm 0.17$ & $46.4 \pm 0.35$ & $46.2 \pm 0.50$ & 0.6373 \\
\hline & $1^{\mathrm{st}}$ & $145.5 \pm 3.14$ & $143.9 \pm 1.67$ & $141.8 \pm 6.12$ & $144.6 \pm 10.36$ & $143.0 \pm 2.50$ & 0.9419 \\
\hline & $2^{\text {nd }}$ & $256.9 \pm 5.86$ & $251.1 \pm 5.80$ & $255.6 \pm 6.12$ & $262.4 \pm 10.25$ & $260.2 \pm 7.85$ & 0.4206 \\
\hline & $3^{\text {rd }}$ & $556.7 \pm 13.10^{\mathrm{a}}$ & $554.3 \pm 10.6^{a}$ & $560.6 \pm 6.86^{a}$ & $551.0 \pm 5.82^{\mathrm{a}}$ & $519.3 \pm 10.3^{b}$ & 0.0026 \\
\hline & 4th & $906.7 \pm 34.06$ & $864.1 \pm 21.17$ & $869.9 \pm 23.36$ & $860.9 \pm 7.90$ & $838.9 \pm 29.01$ & 0.0746 \\
\hline \multirow{4}{*}{$\begin{array}{l}\text { Body weight } \\
\text { gain }(\mathrm{g})\end{array}$} & $1^{\text {st }}$ & $99.3 \pm 2.92$ & $97.9 \pm 2.28$ & $96.0 \pm 6.13$ & $98.2 \pm 10.47$ & $96.9 \pm 2.21$ & 0.9618 \\
\hline & $2^{\text {nd }}$ & $111.4 \pm 8.4$ & $107.2 \pm 4.23$ & $113.8 \pm 8.30$ & $117.8 \pm 0.97$ & $117.2 \pm 5.89$ & 0.2796 \\
\hline & $3^{\text {rd }}$ & $299.8 \pm 7.23^{a}$ & $303.2 \pm 14.14^{\mathrm{a}}$ & $305.1 \pm 4.91^{\mathrm{a}}$ & $288.6 \pm 11.98^{\mathrm{a}}$ & $259.1 \pm 11.59^{b}$ & 0.0017 \\
\hline & 4th & $350.0 \pm 29.17$ & $309.8 \pm 31.70$ & $309.3 \pm 21.91$ & $309.9 \pm 3.59$ & $319.6 \pm 38.12$ & 0.3674 \\
\hline \multirow{4}{*}{$\begin{array}{l}\text { Feed } \\
\text { consumption } \\
\text { (g) }\end{array}$} & $1^{\text {st }}$ & $94.0 \pm 0.85$ & $93.8 \pm 3.11$ & $89.6 \pm 3.99$ & $93.4 \pm 8.00$ & $91.8 \pm 7.34$ & 0.8294 \\
\hline & $2^{\text {nd }}$ & $167.3 \pm 15.43$ & $170.3 \pm 11.26$ & $163.5 \pm 8.03$ & $187.8 \pm 5.13$ & $202.4 \pm 31.85$ & 0.0889 \\
\hline & $3^{\text {rd }}$ & $458.3 \pm 32.95$ & $463.3 \pm 30.53$ & $469.0 \pm 4.56$ & $467.4 \pm 9.81$ & $473.0 \pm 3.41$ & 0.9195 \\
\hline & 4th & $674.5 \pm 53.23$ & $680.3 \pm 10.33$ & $672.6 \pm 7.47$ & $633.0 \pm 33.58$ & $653.0 \pm 74.08$ & 0.6749 \\
\hline \multirow{4}{*}{$\begin{array}{l}\text { Feed } \\
\text { conversion } \\
\text { ratio }\end{array}$} & $1^{\text {st }}$ & $0.95 \pm 0.03$ & $0.96 \pm 0.01$ & $0.93 \pm 0.08$ & $0.95 \pm 0.02$ & $0.95 \pm 0.07$ & 0.9710 \\
\hline & $2^{\text {nd }}$ & $1.51 \pm 0.20$ & $1.59 \pm 0.05$ & $1.44 \pm 0.05$ & $1.60 \pm 0.04$ & $1.73 \pm 0.24$ & 0.2331 \\
\hline & $3^{\text {rd }}$ & $1.53^{\mathrm{C}} \pm 0.09$ & $1.53^{\mathrm{C}} \pm 0.13$ & $1.54^{\mathrm{c}} \pm 0.04$ & $1.62^{b} \pm 0.10$ & $1.83^{\mathrm{a}} \pm 0.07$ & 0.0098 \\
\hline & 4th & $1.93 \pm 0.05$ & $2.21 \pm 0.19$ & $2.18 \pm 0.17$ & $2.04 \pm 0.12$ & $2.07 \pm 0.44$ & 0.6003 \\
\hline
\end{tabular}

${ }^{a-c}$ Mean \pm SD values with different superscripts within same row differ significantly; NS, Non-significant; * $\mathrm{p}<0.05, * *, \mathrm{p}<0.01$. 
Husna et al. (2017) Bang. J. Anim. Sci. 46 (2):88-94

Table 3. The overall Performances of broilers fed on oil extracted KSC at different ages

\begin{tabular}{|c|c|c|c|c|c|c|}
\hline \multirow[t]{2}{*}{ Parameters } & \multicolumn{5}{|c|}{ Different treatment groups (Mean \pm SD) } & \multirow{2}{*}{$\begin{array}{l}\text { Significant } \\
\text { level }\end{array}$} \\
\hline & $\begin{array}{l}0 \% \text { KSC diet } \\
\text { from 1st day }\end{array}$ & $\begin{array}{l}2 \% \text { KSC diet } \\
\text { from } 21 \text { day }\end{array}$ & $\begin{array}{l}2 \% \text { KSC diet } \\
\text { from } 14 \text { day }\end{array}$ & $\begin{array}{l}2 \% \text { KSC diet } \\
\text { from } 7 \text { day }\end{array}$ & $\begin{array}{l}2 \% \text { KSC diet } \\
\text { from } 1 \text { st day }\end{array}$ & \\
\hline Initial weight $(\mathrm{g})$ & $46.22 \pm 0.35$ & $46.06 \pm 0.68$ & $45.83 \pm 0.17$ & $46.39 \pm 0.35$ & $46.17 \pm 0.50$ & 0.6373 \\
\hline $\begin{array}{l}\text { Final weight } \\
\text { (g) }\end{array}$ & $\begin{array}{r}906.69 \pm \\
34.06\end{array}$ & $\begin{array}{r}864.05 \pm \\
21.17\end{array}$ & $\begin{array}{r}869.92 \pm \\
23.36\end{array}$ & $\begin{array}{r}860.87 \pm \\
7.90\end{array}$ & $\begin{array}{r}838.89 \pm \\
29.01\end{array}$ & 0.0746 \\
\hline $\begin{array}{l}\text { Body weight gain } \\
\text { (g) }\end{array}$ & $\begin{array}{r}860.47 \pm \\
34.28\end{array}$ & $\begin{array}{r}818.00 \pm \\
21.84\end{array}$ & $\begin{array}{r}824.08 \pm \\
23.43\end{array}$ & $\begin{array}{r}814.48 \pm \\
8.17\end{array}$ & $\begin{array}{r}792.72 \pm \\
28.70\end{array}$ & 0.0766 \\
\hline $\begin{array}{l}\text { Feed } \\
\text { consumption }(\mathrm{g})\end{array}$ & $\begin{array}{r}1394.05 \pm \\
97.94\end{array}$ & $\begin{array}{r}1407.67 \pm \\
26.77\end{array}$ & $\begin{array}{r}1394.67 \pm \\
16.46\end{array}$ & $\begin{array}{r}1381.50 \pm \\
37.70\end{array}$ & $\begin{array}{r}1420.19 \pm \\
39.92\end{array}$ & 0.9089 \\
\hline $\begin{array}{l}\text { Feed Conversion } \\
\text { Ratio }\end{array}$ & $1.62 \pm 0.05$ & $1.72 \pm 0.02$ & $1.69 \pm 0.07$ & $1.70 \pm 0.07$ & $1.79 \pm 0.10$ & 0.0963 \\
\hline Survivability & 100 & 100 & 100 & 97.22 & 100 & 0.4516 \\
\hline
\end{tabular}

\section{Feed Conversion Ratio (FCR)}

The feed conversion ratio (FCR) of broilers receiving different dietary treatments is shown in Table 2. The feed conversion ratio (FCR) of broilers were not significantly different $(p>0.05)$ at day 7,14 and 28 . Only significant differences were found at the age of 14 to 21 days $(p=0.0098)$. At this age, significantly poor FCR was found in $T_{5}$ and better FCR was found in $T_{1}$ and $T_{2}$. No significant differences were found in FCR among different treatments in whole experimental period of 28 days. In the whole experimental period FCR was 1.62, 1.72, 1.69, 1.70 and 1.79 in the treatments $T_{1}, T_{2}, T_{3}, T_{4}$ and $T_{5}$, respectively. Habib et al. (2016) did not found any significant difference in FCR between control and $2 \% \mathrm{KSC}$ fed diet for broilers during 28 days experimental period.
Dhara et al. (1997) observed poor feed efficiency by dietary incorporation of $11.20 \%$ to $22.40 \%$ deoiled karanj cake in the diet of Japanese quail. But, Natnam et al. (1989) reported comparable feed efficiency with control diet in broiler chicks by incorporating solvent extracted karanj cake at $10 \%$ level in the diet. Efficiency of feed utilization depends on the level of protein and energy (Mellen et al., 1984) and their ratio (Davidson, 1964 ) in addition to the presence of incriminated factors (Chand, 1987) and the balance of nutrients in the diet (Combs, 1964). Probably the presence of residual incriminating factors in deoiled koroch cake resulted in poor FCR in broiler chicks despite feeding of uniformly balanced diets in other experiment. However, in our experiment KSC diet did not affect FCR fed at different ages of broiler due to incorporation of $\mathrm{KSC}$ in the diet at lower level (only $2 \%$ ).

Table 4. Meat yield characteristics of broilers fed on oil extracted KSC at different ages

\begin{tabular}{|c|c|c|c|c|c|c|}
\hline \multirow[t]{2}{*}{ Parameters } & \multicolumn{5}{|c|}{ Different treatment groups } & \multirow{2}{*}{$\begin{array}{l}\text { Level of } \\
\text { Significan } \\
\text { ce }\end{array}$} \\
\hline & $\begin{array}{l}0 \% \text { KSC diet } \\
\text { from } 1 \text { st day }\end{array}$ & $\begin{array}{l}2 \% \text { KSC diet } \\
\text { from } 21 \text { day }\end{array}$ & $\begin{array}{l}2 \% \text { KSC diet } \\
\text { from } 14 \text { day }\end{array}$ & $\begin{array}{l}2 \% \text { KSC diet } \\
\text { from } 7 \text { day }\end{array}$ & $\begin{array}{l}2 \% \text { KSC diet } \\
\text { from 1st day }\end{array}$ & \\
\hline Live weight (g) & 924.7 & 911.0 & 927.0 & 910.3 & 912.7 & NS \\
\hline $\begin{array}{l}\text { Dressing } \\
\text { yield }(\mathrm{g})\end{array}$ & 66.19 & 63.63 & 62.33 & 66.76 & 67.20 & NS \\
\hline $\operatorname{Blood}(\mathrm{g})$ & 4.77 & 3.82 & 4.24 & 4.19 & 5.12 & NS \\
\hline Feather(g) & 2.49 & 3.50 & 5.16 & 2.83 & 3.28 & NS \\
\hline $\operatorname{Neck}(g)$ & 2.42 & 1.93 & 2.19 & 2.27 & 2.30 & NS \\
\hline $\operatorname{Head}(\mathrm{g})$ & 2.96 & 2.93 & 3.31 & 3.48 & 2.93 & NS \\
\hline Gizzard(g) & 2.41 & 2.34 & 2.70 & 2.35 & 2.52 & NS \\
\hline Heart(g) & 0.58 & 0.55 & 0.47 & 0.66 & 0.51 & NS \\
\hline Liver(g) & 2.77 & 3.33 & 2.87 & 3.01 & 3.07 & NS \\
\hline Shank(g) & 2.27 & 2.16 & 2.45 & 2.12 & 2.23 & NS \\
\hline Breast(g) & 11.90 & 12.79 & 11.36 & 11.79 & 11.48 & NS \\
\hline Drumstick(g) & 9.01 & 9.23 & 9.84 & 8.64 & 9.27 & NS \\
\hline Thigh(g) & 9.73 & 9.16 & 8.84 & 9.58 & 9.14 & NS \\
\hline Wing(g) & 8.29 & 8.12 & 7.91 & 8.58 & 8.32 & NS \\
\hline $\operatorname{skin}(g)$ & 3.32 & 2.27 & 2.44 & 2.45 & 3.36 & NS \\
\hline $\begin{array}{l}\text { Abdominal } \\
\text { fat }(g)\end{array}$ & 0.72 & 0.81 & 0.83 & 0.87 & 0.61 & NS \\
\hline
\end{tabular}




\section{Koroch seed on performances of broiler}

\section{Meat yield characteristics}

The data on carcass traits like dressing percentage, percent live weight of neck, head, gizzard, heart, liver, shank, breast, drumstick, thigh, wing, skin and abdominal fat have been set out in Table 4. All the parameters determined showed a non-significant treatment effect. Mandal and Banerjee (1982) reported no difference on organ weights like; liver, heart, kidney and spleen of cockerels due to dietary replacement of black til cake with deoiled karanj cake at 30\% level. Dhara et al. (1997) also found no significant variation in weight of different commercial cuts (neck, wing, thigh, shank, breast and trunk) and organs (giblet, liver, heart and gizzard) due to incorporation of deoiled karanj cake up to $22.40 \%$ in the diet of Japanese quail. The results of our experiment agreed with these previous results. However, Panda et al. (2006) observed the dietary inclusion of either solvent extracted karanj cake (SKC) or $\mathrm{NaOH}$ treated SKC at $25 \%$ level and $\mathrm{Ca}(\mathrm{OH})_{2}$ treated SKC at $12.5 \%$ and $25 \%$ levels significantly increased the weight of liver leading to liver hypertrophy. Gizzard weight also increased significantly due to incorporation of SKC at both the levels. Although in our experiment, no significant results were found in liver and gizzard weight, lower weight of gizzard and liver was found in control group (without KSC fed whole experimental group) $(P>0.05)$.

\section{Conclusion}

The results revealed that the feeding of $2 \%$ koroch seed cake at different ages of broilers had no improved growth rate and feed conversion efficiency during 28 days of experimental period. The performance of control diet and KSC diet was similar. In the economic view, Koroch seed is cheaper and available in Bangladesh. Using this cake as protein source may reduce pressure on soybean meal.

\section{Acknowledgement}

The authors would like to express their cordial thanks to Bangladesh Agricultural University Research System (BAURES) for the full financial support of conducting this research work.

\section{References}

Allen ON and EK Allen (1981). The Leguminosae. The University of Wisconsin Press. $812 \mathrm{p}$.

AOAC (1995). Association of Official Analytical Chemistry, Official Methods of Analysis. (13th edn.) Washington, DC.

Amata IA (2014). The Use of Non-Conventional Feed Resources (Ncfr) for Livestock Feeding in the Tropics. Journal of Global Biosciences, 3: 604-613.

Banerjee GC (1998). Poultry.Third edition. Oxford \& IBH Publishing Company Pvt Ltd. Calcutta. 120-121pp.

Chand S (1987). Nutritional Evaluation of Neem Seed Meal in Chicks. Ph.D. Thesis, Rohilkhand University, Bareilly.

Combs GF (1964). Predicting Amino Acid Requirement of Chicks Based on Growth Rate, Body Size and Body Composition. Feed Processing, 23:46-48.

Davidson J (1964). The Effciency of Conversion of Dietary Metabolizable Energy into Tissue Energy in Chicken as Measured By Body Analyses. European Association of Animal Production; $3^{\text {rd }}$ symposium on Energy Metabolism.

Dhara TK, N Chakraborty, G Samanta and L Mandal (1997). Deoiled karanj (P.glabravent) Cake in the ration of Japanese quail. Indian Journal of Poultry Science, 32:132-136.

James AD (1983). Handbook of Energy Crops. Unpublished.

http://www.hortpurdue.edu/duke_ energy/p ongamiapinnata.htm.

Habib M, AJM. Ferdaus, MT Islam, BM Hassin and MS Ali (2016). Performance of broiler fed on diet containing deoiledKoroch (PongamiaPinnata) seed cake treated with $\mathrm{NaOH}$ and $\mathrm{HCl}$. Research in Agriculture, Livestock and Fisheries, 3 (2): 323-329.

Mandal L and GC Banerjee (1979). Studies on the Utilization of Karanja (Pongamia glabra Vent.) Cake in Layer Diet. Indian Journal of Poultry Science, 14:105-109.

Mandal L and GC Banerjee (1982). Studies on the Utilization of Karanj (Pongamia glabra) Cake in Poultry Rations Effect on Growers on Blood Composition and Organ Weight of Cockerels. Indian Veterinary Journal, 59: 385-390. 
Husna et al. (2017) Bang. J. Anim. Sci. 46 (2):88-94

Mellen WJ, FW Hill and HH Dukes (1984). Studies on the Energy Requirement of Chickens,2 Effect and Dietary Energy Level on Basal Metabolism of Growing Chickens. Poultry Science, 31: 735-740.

Natanam R, R Kadirvel and R Ravi (1989). The Toxic Effects of Karanja (Pongamia glabra Vent) Oil and Cake On Growth and Feed Efficiency in Broiler Chicks. Animal Feed Science Technology. 27:95-100.

Panda AK, VRB Sastry, A Kumar and SK Saha (2006). Quantification of Karanjin, Tannin and Trypsin Inhibitors in Raw and Detoxified Expeller and Solvent Extracted Karanj (Pongamia glabra) cake. Asian-Australian Journal of Animal Science, 19: 1776-1783.

Pavanaram SK and RL Ramachandra (1995). New Flavones from Pongamia pinnata (L.) Merr.: Identification of Compound D. Nature, 176:11774-5.

SAS (2009). Users Guide: Statistics. Version 9.2, SAS Institute Inc., Cary, NC. USA

Singh RA (1990). Poultry Production, $3^{\text {rd }}$ edition. Kalyany Publishers, New Delhi, Ludhiana. 